\title{
PENGARUH PEMBERIAN MIKROBA EFEKTIF PRODUKTIF PLUS (MEP+) PADA MEDIUM BUDIDAYA IKAN NILA YANG DIBERI PAKAN FERMENTATIF TERHADAP KEPADATAN BAKTERI ASAM LAKTAT
}

\author{
Nita WULANDARI, SUKANTO, ENDANG WIDYASTUTI
}

Fakultas Biologi, Universitas Jenderal Soedirman, Jalan dr. Suparno 63 Purwokerto 53122

\section{A B S T R A C T}

Microbes Effective Productive Plus (MEP+) in fish culture has role as probiotics and decomposer. Application of MEP+ is done by adding $\mathrm{MEP}^{+}$on culture medium of Tilapia and fish feed. Fish feed is fermentative feed with addition of different concentration of cassava peel flour. The aim of this research were to find out the influence of MEP+ administration in culture medium and in fermentative feed with addition cassava peel flour on the increasing density of lactic acid bacteria in culture medium and find out the highest density of lactic acid bacteria. The research was done experimentally, used Complete Randomized Design with treatment of MEP+ administration in culture medium with fermentative feed cassava peel flour addition of $25 \%, 50 \%, 75 \%$ and without MEP+ administration on culture medium with fermentative feed cassava peel flour addition of $25 \%$. The data obtained were analyzed using a variety analysis. The result showed that $\mathrm{MEP}^{+}$administration on culture medium and in fermentative feed cassava peel flour addition did not influence the increasing density of lactic acid bacteria and total density of lactic acid bacteria in culture medium was not different inter treatment.

KEY WoRDS: Microbes Effective Productive Plus (MEP+), culture medium, Nila, fermentative feed, lactic acid bacteria

Penulis korespondensi: NITA WULANDARI | email: ntaonta@gmail.com

\section{PENDAHULUAN}

Mikroba Efektif Produktif Plus (MEP+) merupakan probiotik berupa kultur campuran spesies indigenous mikroba Gram positif non patogen bersifat amilolitik, selulolitik, proteolitik, dan lipolitik negatif. Kultur bakteri yang terkandung dalam $\mathrm{MEP}^{+}$yaitu campuran bakteri asam laktat diantaranya Lactobacillus brevis, $L$. delbrueckii, Lactococcus lactis, dan bakteri selulolitik yaitu Cellulomonas cellasea (Sukanto dan Sutardi, 2008). Bakteri asam laktat termasuk bakteri yang menghasilkan asam laktat sebagai hasil akhir dari metabolisme gula (karbohidrat) (Suprihatin, 2010).

Probiotik dalam budidaya ikan dapat diberikan ke dalam pakan maupun medium budidaya. Menurut Purwanta et al. (2002) probiotik dapat diaplikasikan pada lingkungan perairan yang bertujuan memperbaiki kualitas lingkungan perairan. Kualitas air yang baik diharapkan dapat memberikan pengaruh positif bagi kelangsungan hidup ikan Nila. Penerapan $\mathrm{MEP}^{+}$dalam penelitian ini diberikan pada medium budidaya ikan Nila (Oreochromis niloticus) dengan pakan fermentatif menggunakan campuran tepung kulit ubi kayu (Manihot esculenta Cranz). Menurut Muhiddin et al. (2001) fermentasi kulit umbi ubi kayu mampu meningkatkan kandungan protein dan mengurangi masalah limbah pertanian.

Aplikasi $\mathrm{MEP}^{+}$biasa diberikan pada pakan ternak, air minum ternak dan pakan ikan. Selama ini belum pernah ada informasi penelitian pemberian $\mathrm{MEP}^{+}$ pada medium budidaya ikan. Berdasarkan hal tersebut mendorong dilakukannya suatu penelitian pemberian $\mathrm{MEP}^{+}$pada medium budidaya ikan untuk mengetahui $\mathrm{MEP}^{+}$memiliki andil atau tidak jika diberikan pada perairan, yaitu dengan cara dilihat dari jumlah dan kepadatan bakteri asam laktat pada medium budidaya ikan. Kondisi bakteri asam laktat medium budidaya pada penelitian ini dipengaruhi pula oleh hasil buangan ikan berupa feses dan sisa pakan yang mengendap pada dasar bak percobaan.

\section{ME T ODE}

Penelitian dilakukan di Stasiun Percobaan D3 Fakultas Biologi Unsoed, pengamatan jumlah kepadatan bakteri asam laktat medium budidaya dilakukan di laboratorium Mikrobiologi Fakultas Biologi Unsoed, dan laboratorium Lingkungan Fakultas Biologi Unsoed untuk pengamatan kualitas fisika kimia air. Waktu pelaksanaan penelitian dilakukan mulai bulan Agustus 2011 sampai November 2011.

Bahan-bahan yang digunakan dalam penelitian diantaranya adalah probiotik $\mathrm{MEP}+$ cair, air, ikan nila, agar, medium selektif MRSA (De Man Rogosa and Sharpe Agar), akuades, alkohol 70\%, spirtus, pakan fermentatif (bahan baku: tepung kulit ubi kayu, dedak, ampas tahu, tepung ikan, limbah budidaya jamur, $\mathrm{MEP}^{+}$tepung, tepung kanji, dan CMC). Alat-alat yang digunakan dalam penelitian diantaranya bak fiber berukuran $60 \mathrm{~cm} \times 40 \mathrm{~cm}$ x $60 \mathrm{~cm}$, botol sampel steril, autoklaf model HL36AE, Erlenmeyer, gelas ukur, batang pengaduk, cawan Petri, tabung reaksi, pembakar spiritus, mikropipet ukuran $1 \mathrm{ml}$ dan 0,1 ml, tip ukuran $1 \mathrm{ml}$ dan 0,1 ml, drugalsky, inkubator.

Penelitian dilakukan secara eksperimental menggunakan rancangan dasar, yaitu rancangan acak lengkap (RAL). Percobaan terdiri dari 4 perlakuan dengan 4 kali ulangan, didapatkan 16 unit percobaan. Pengambilan sampel dilakukan 4 kali dengan interval 3 minggu sekali. Perlakuan yang dicobakan meliputi $\mathrm{A}$ : pemberian $\mathrm{MEP}^{+}$ pada medium budidaya ikan nila dengan pakan fermentatif berbahan tepung kulit ubi kayu 25\%; B : pemberian $\mathrm{MEP}^{+}$ pada medium budidaya ikan nila dengan pakan fermentatif berbahan tepung kulit ubi kayu 50 \%; C : pemberian $\mathrm{MEP}^{+}$ pada medium budidaya ikan nila dengan pakan fermentatif berbahan tepung kulit ubi kayu 75\%; dan D : tanpa pemberian $\mathrm{MEP}^{+}$pada medium budidaya ikan nila dengan 
pakan fermentatif berbahan tepung kulit ubi kayu 25\%. Parameter utama yang diamati adalah jumlah bakteri asam laktat pada medium budidaya ikan. Parameter pendukung berupa kondisi fisika dan kimia air, parameter fisika meliputi pengukuran temperatur sedangkan parameter kimia meliputi pengukuran $\mathrm{pH}$, oksigen terlarut (DO), Nitrit $\left(\mathrm{NO}_{2}\right)$, Biological Oxygen Demand (BOD), Chemical Oxygen Demand (COD), dan total fosfat sebagai $\mathrm{P}$ ( $\left.\mathrm{PO}_{4}-\mathrm{P}\right)$, pemeriksaan kepadatan bakteri asam laktat pada usus ikan nila, serta analisis proksimat pakan.

Persiapan bak fiber sebanyak berukuran $60 \mathrm{~cm}$ x $40 \mathrm{~cm}$ x $60 \mathrm{~cm}$ sebelumnya dibersihkan dan dicuci dengan kalium permanganat $\left(\mathrm{KMnO}_{4}\right) \quad 0,5 \%$ selama 24 jam, selanjutnya dibilas dengan air. Bak dilengkapi aerator, kemudian diisi dengan air kolam sebanyak $3 / 4$ dari total volume bak, untuk pengganti air yang menguap ditambahkan dengan air sumur. Ikan Nila sebelum di tebar diaklimatisasi selama 3 hari, kemudian di timbang bobot dan di ukur panjangnya, kemudian ditempatkan kedalam 16 bak masing-masing 10 ekor. Ikan diberi pakan setiap hari sebanyak 3\% dari bobot ikan pada pagi $1,5 \%$ dan sore $1,5 \%$. Pengukuran bobot ikan dan pengukuran panjang ikan dilakukan setiap dua minggu sekali.

Media pertumbuhan untuk bakteri asam laktat yaitu menggunakan media MRSA. Media MRSA dan agar ditambahkan akuades kemudian dipanaskan hingga larut dan media dapat memadat. Media yang telah homogen disterilisasi dengan autoklaf kemudian dituangkan ke dalam cawan petri steril, setelah memadat dibungkus plastik cling untuk mencegah kontaminasi.

Pengamatan sampel bakteri asam laktat dilakukan dengan mengambil air menggunakan botol sampel steril, dari setiap perlakuan diambil sebanyak $\pm 50 \mathrm{ml}$. Pengambilan sampel air dilakukan pada 5 titik permukaan air bak kemudian dihomogenkan. Air dari bak A1, A2, A3, A4 dihomogenkan menjadi sampel air A. Untuk pengambilan sampel air B,C,D dilakukan sama seperti pada pengambilan sampel air A. Inokulasi sampel pada media MRSA dilakukan pengenceran bertingkat sampai $10^{-2}$. Hasil pengenceran $10^{-1}$ dan $10^{-2}$ masing-masing di platting duplo secara spread plate (sebar). Hasil platting diinkubasi $2 \times 24$ jam pada suhu $30^{\circ} \mathrm{C}$.

Pengambilan usus ikan nila dilakukan dengan cara diambil sebanyak 2 ekor ikan kemudian dibedah dan diambil ususnya sebanyak 1 gram secara aseptis, kemudian dimaserasi, dilakukan pengenceran bertingkat sampai $10^{-4}$. Dua pengenceran terkhir di platting duplo secara spread plate, kemudian diinkubasi $2 \times 24$ jam pada suhu $30^{\circ} \mathrm{C}$. Pemeriksaan kualitas fisika kimia pada medium budidaya ikan nila pengukuran temperatur, $\mathrm{pH}$, Oksigen Terlarut (DO), Nitrit $\left(\mathrm{NO}_{2}\right)$, Biological Oxygen Demand (BOD), Chemical Oxygen Demand) (COD), dan total fosfat sebagai $\mathrm{P}$ $\left(\mathrm{PO}_{4}-\mathrm{P}\right)$. Sedangkan pemeriksaan pakan fermentatif dilakukan uji kadar protein dan serat kasar pakan.

Pengamatan jumlah bakteri asam laktat dilakukan dengan menghitung jumlah koloni yang tumbuh. Koloni bakteri diamati morfologi koloninya. Jumlahnya dihitung dengan menggunakan metode Standard Plate Count (SPC). Data jumlah bakteri asam laktat medium budidaya ikan Nila selanjutnya dianalisa dengan one way analisis of variance (ANOVA). Dianalisa pada tingkat kepercayaan 95\% dan 99\%. Analisis yang digunakan berdasarkan Siregar, (2005).

\section{HASIL DAN PEMBAHASAN}

Pengaruh pemberian $\mathrm{MEP}^{+}$pada medium budidaya ikan nila yang diberi pakan fermentatif berbahan tepung kulit ubi kayu sebesar 25\%, 50\%, 75\% dengan pengambilan sampel dilakukan empat kali ulangan interval 3 minggu sekali dapat dilihat pada Gambar 1. Berdasarkan pengamatan kepadatan bakteri asam laktat medium budidaya menunjukkan kepadatan yang berbeda-beda pada setiap periode pengambilan sampel.

Kepadatan bakteri asam laktat selama pengamatan setelah dilakukan transformasi dalam log diperoleh jumlah berkisar antara $3 \mathrm{sel} / \mathrm{ml}$ sampai dengan 3,55 sel/ml. Berdasarkan Gambar 1 kepadatan bakteri asam laktat pada pengambilan sampel ke-1 dilakukan pada minggu ke-0, terlihat bahwa kepadatan bakteri asam laktat pada perlakuan A, B, C, D sama. Pengambilan sampel ke-2 dilakukan pada minggu ke3 , terlihat bahwa terjadi peningkatan kepadatan bakteri asam laktat pada perlakuan A, B, C, D. Pengambilan sampel ke-3 dilakukan pada minggu ke6 , terlihat bahwa terjadi penurunan kepadatan bakteri asam laktat pada perlakuan A, B, C sedangkan pada perlakuan D mengalami peningkatan.

Pengambilan sampel ke-4 dilakukan pada minggu ke-9, terlihat bahwa terjadi peningkatan kepadatan bakteri asam laktat pada perlakuan A, B, sedangkan pada perlakuan C, D mengalami penurunan. Berdasarkan grafik di atas pada minggu ke-9 kepadatan bakteri asam laktat pada perlakuan A, C, D jumlahnya tidak jauh berbeda berkisar antara 3,2 $\mathrm{sel} / \mathrm{ml}$ sampai $3,3 \mathrm{sel} / \mathrm{ml}$ kecuali pada perlakuan B karena terjadi penurunan drastis pada minggu ke- 6 sehingga bakteri asam laktat pada perlakuan B peningkatannya tidak terlalu tinggi. Data jumlah kepadatan bakteri asam laktat medium budidaya ikan nila tersaji pada Tabel 1 .

Kepadatan bakteri asam laktat medium budidaya ikan nila masing-masing perlakuan diuji statistik menggunakan analisis ragam (ANOVA) transformsi dalam log. Hasil perhitungan ANOVA tersaji pada Tabel 2.

Berdasarkan perhitungan statistik diperoleh hasil bahwa nilai $F$ hitung $(0,99)$ lebih kecil dari $F$ tabel $(4,07)$, hasil yang didapatkan tidak signifikan. Hal ini berarti pemberian $\mathrm{MEP}^{+}$pada medium budidaya ikan dan pakan fermentatif berbahan tepung kulit ubi kayu yang berbeda tidak berpengaruh terhadap kepadatan bakteri asam laktat medium budidaya ikan nila.

Berdasarkan uraian dan hasil analisis data menunjukkan bahwa $\mathrm{MEP}^{+}$yang diberikan pada medium budidaya ikan dan pakan fermentatif berbahan tepung kulit ubi kayu tidak mempengaruhi terhadap peningkatan bakteri asam laktat medium budidaya karena kepadatannya relatif sama. Kepadatan bakteri asam laktat yang paling tinggi secara kuantitatif pada perlakuan C (pemberian $\mathrm{MEP}^{+}$ dalam medium budidaya ikan nila dengan pakan fermentatif berbahan tepung kulit ubi kayu 75\%).

Kepadatan bakteri asam laktat yang rendah diperkirakan karena pada saat pengambilan sampel air hanya dilakukan pada bagian permukaan bak percobaan saja serta saat pengambilan sampel air tidak dilakukan pengadukan air terlebih dahulu, dapat menjadi faktor lain yang mengakibatkan rendahnya 
kepadatan bakteri asam laktat medium budidaya, karena bakteri asam laktat yang terambil hanya pada permukaan air saja. Hal ini tidak sesuai dengan pernyataan Hadi (2006) bahwa pengambilan sampel bakteri pada media pemeliharaan dilakukan setelah pengadukan secara perlahan untuk mensuspensikan kembali endapan yang terdapat di dasar, karena jumlah bakteri pada sedimen biasanya lebih tinggi daripada badan airnya.
Dengan demikian didapatkannya bakteri asam laktat pada medium budidaya bermanfaat sebagai dekomposer yang dapat memperbaiki kualitas lingkungan perairan sesuai dengan pernyataan Hadioetomo (1993), kelompok bakteri asam laktat apabila berada dalam saluran pencernaan inang (internal) berperan sebagai probiotik dan apabila berada pada lingkungan sekitar (eksternal) berperan aktif sebagai dekomposer.

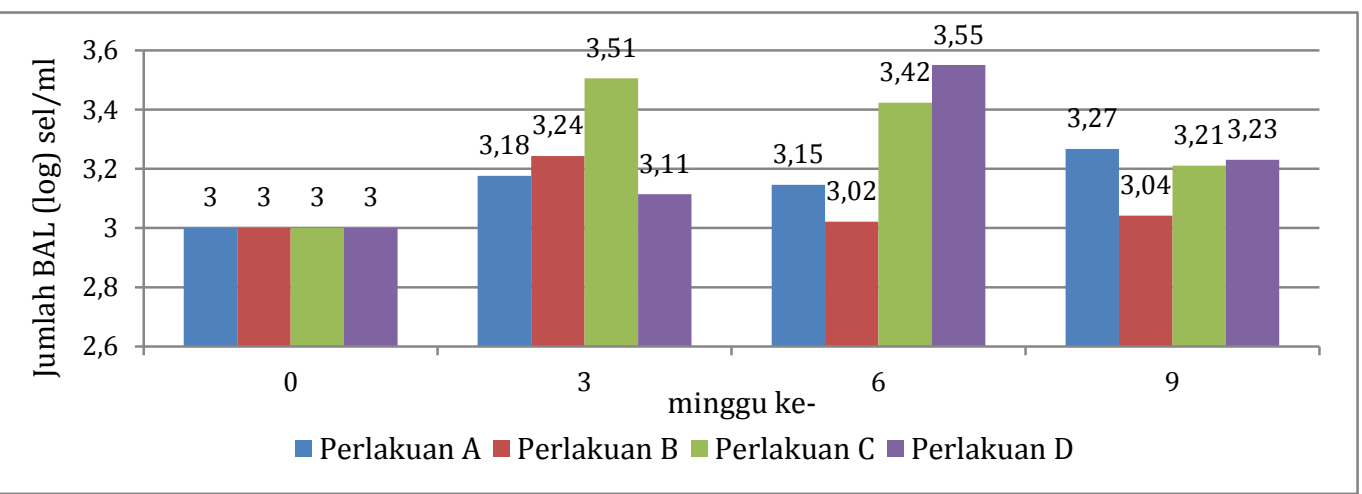

Gambar 1. Histogram Rata-rata kepadatan bakteri asam laktat (sel/ml) medium budidaya ikan nila masing-masing perlakuan pada tiap pengambilan sampel (minggu ke-0, ke-3, ke-6, ke-9).

Keterangan: Perlakuan A (pemberian MEP+ pada medium budidaya ikan nila dengan pakan fermentatif berbahan tepung kulit ubi kayu 25\%); Perlakuan B (pemberian MEP+ pada medium budidaya ikan nila dengan pakan fermentatif berbahan tepung kulit ubi kayu 50\%); Perlakuan C (pemberian $\mathrm{MEP}^{+}$pada medium budidaya ikan nila dengan pakan fermentatif berbahan tepung kulit ubi kayu 75\%); Perlakuan D (tanpa $\mathrm{MEP}^{+}$pada medium budidaya ikan nila dengan pakan fermentatif berbahan tepung kulit ubi kayu 25\%)

Tabel 1. Jumlah kepadatan bakteri asam laktat medium budidaya ikan nila (sel/ml) pada setiap perlakuan selama 9 minggu pemeliharaan (Transformasi dalam log)

\begin{tabular}{|c|c|c|c|c|c|c|c|}
\hline \multirow{2}{*}{ Perlakuan } & \multicolumn{4}{|c|}{ Ulangan } & \multirow{2}{*}{ Total } & \multirow{2}{*}{ Rataan } & \multirow{2}{*}{$\begin{array}{l}\text { Standar } \\
\text { Deviasi }\end{array}$} \\
\hline & 1 & 2 & 3 & 4 & & & \\
\hline A & 3 & 3,18 & 3,15 & 3,27 & 12,59 & 3,15 & 0,11 \\
\hline B & 3 & 3,24 & 3,02 & 3,04 & 12,31 & 3,08 & 0,11 \\
\hline $\mathrm{C}$ & 3 & 3,51 & 3,42 & 3,21 & 13,14 & 3,28 & 0,23 \\
\hline $\mathrm{D}$ & 3 & 3,11 & 3,55 & 3,23 & 12,89 & 3,22 & 0,24 \\
\hline Total & & & & & 50,93 & 12,73 & \\
\hline
\end{tabular}

Tabel 2. Analisis ragam (ANOVA) pengaruh pemberian MEP+ pada medium budidaya ikan dan pakan fermentatif berbahan tepung kulit ubi kayu yang berbeda terhadap kepadatan bakteri asam laktat di medium budidaya.

\begin{tabular}{|c|c|c|c|c|c|c|}
\hline Sumber & Derajat & Jumlah & Kuadrat & \multirow{2}{*}{ F Hitung } & \multicolumn{2}{|c|}{ F Tabel } \\
\hline Variasi & Bebas (DB) & Kuadrat (JK) & Tengah (KT) & & 0.05 & 0.01 \\
\hline Perlakuan & 3 & 0,10 & 0,03 & 0,99 & 4,07 & 7,59 \\
\hline Galat & 12 & 0,40 & 0,03 & & & \\
\hline Total & 15 & 0,50 & & & & \\
\hline
\end{tabular}

Menurut Suriawiria (1986) proses dekomposisi senyawa organik oleh mikroba merupakan proses berantai. Senyawa organik yang bersifat heterogen, bercampur dengan kumpulan jasad hidup yang berasal dari udara, tanah, dan air atau sumber lainnya, dan di dalamnya terjadi proses mikrobiologis. Proses dekomposisi yang baik dapat mempengaruhi terhadap kualitas perairan.

Kualitas air yang terdiri dari komponen fisika, kimia, dan biologi perlu diperhatikan dalam kegiatan budidaya ikan. Faktor kualitas air mempengaruhi kehidupan organisme didalamnya. Peraturan Pemerintah Nomor 82 tahun 2001 mengemukakan baku mutu air kelas III bagi peruntukan pembudidayaan ikan air tawar, peternakan, air untuk mengairi pertanaman, dan atau peruntukan lain yang mensyaratkan mutu air yang sama dengan kegunaan tersebut (KLH, 2002). Hasil pengukuran parameter fisika kimia medium budidaya tersaji pada Tabel 3.

Pertumbuhan dan kehidupan biota air dipengaruhi oleh suhu, karena dapat mempengaruhi aktivitas metabolisme dan berpengaruh pula terhadap kelarutan oksigen dalam air. suhu yang terlalu tinggi menyebabkan daya larut oksigen rendah (Ghufran, 2007). Kisaran suhu bagi pertumbuhan bakteri $L$. brevis yaitu pada $10^{\circ} \mathrm{C}-45^{\circ} \mathrm{C}$, L. delbrueckii pada $37^{\circ} \mathrm{C}$ - $45^{\circ} \mathrm{C}$, Lc. lactis pada $20-30^{\circ} \mathrm{C}$ (Widiada, 2008), dan $C$. cellasea pada $28-33^{\circ} \mathrm{C}$ (Breed et al., 1957 dalam Wahyudi, 2008). Sedangkan Suyanto (1999) menyatakan bahwa kisaran suhu untuk pertumbuhan 
dan perkembangan ikan nila sebesar $25-30^{\circ} \mathrm{C}$. Kondisi suhu air pada penelitian ini masih kurang memenuhi syarat untuk pertumbuhan bakteri $\mathrm{MEP}^{+}$tetapi masih memenuhi syarat untuk pertumbuhan ikan nila.

Peran $\mathrm{pH}$ dalam perairan dapat mempengaruhi kesuburan perairan karena mempengaruhi kehidupan jasad renik (Ghufran, 2007). L. brevis, L. delbrueckii, dan Lc. lactis dapat menghasilkan asam laktat dan asam asetat yang dapat menurunkan $\mathrm{pH}$ media (Wahyudi, 2008). Sifat dari L. brevis dan L. delbruecki termasuk Gram positif, bentuk basil sedangkan $L c$. lactis termasuk Gram positif, bentuk coccus. $\mathrm{pH}$ bagi pertumbuhan bakteri L. brevis, L. delbrueckii, dapat tumbuh pada kisaran pH 4,5 - 9,6 sedangkan Lc. lactis dengan kisaran pH sekitar 4,5 - 6,5 (Widiada,2008). Ketiga bakteri tersebut dapat menghasilkan asam laktat dan asam asetat yang dapat menurunkan $\mathrm{pH}$ media, $\mathrm{pH}$ asam tidak cocok untuk pertumbuhan bakteri lain (Wahyudi, 2008). Kisaran pH untuk pertumbuhan $C$. cellasea yaitu berkisar antara $7-7,5$ (Thayer at al., 1984). Sedangkan menurut Suyanto (1999) $\mathrm{pH}$ air tempat hidup ikan nila berkisar antara 6-8,5. Namun pertumbuhan optimal pada kisaran $\mathrm{pH}$ 7-8. Kondisi $\mathrm{pH}$ air pada penelitian ini masih memenuhi syarat untuk untuk pertumbuhan bakteri asam laktat $\mathrm{MEP}^{+}$dan ikan nila.

Tabel 3. Parameter fisika kimia medium budidaya ikan nila pada masing-masing perlakuan

\begin{tabular}{llcccccl}
\hline No & \multicolumn{1}{c}{ Parameter } & \multirow{2}{*}{ Satuan } & A & B & C & D & $\begin{array}{c}\text { Baku Mutu Perairan Kelas III } \\
\text { (PP No 82 tahun 2001) }\end{array}$ \\
\hline 1 & Suhu & ${ }^{0} \mathrm{C}$ & 24 & 26 & 25 & 25 & $\begin{array}{l}\text { Mengikuti deviasi temperatur } \\
\text { keadaan alamiah }\end{array}$ \\
2 & $\mathrm{pH}$ & & 7 & 7 & 6 & 7 & 6 -9 \\
3 & $\mathrm{DO}$ & $\mathrm{mg} / \mathrm{l}$ & $3,25 \pm 0,91$ & $2,89 \pm 1,53$ & $2,95 \pm 1,18$ & $3,05 \pm 2,16$ & 3 (Batas Minimum) \\
4 & $\mathrm{NO}_{2}$ sbg & $\mathrm{mg} / \mathrm{l}$ & $0,06 \pm 0,06$ & $0,10 \pm 0,13$ & $0,33 \pm 0,61$ & $0,13 \pm 0,13$ & 0,06 \\
5 & $\mathrm{NOD}\left(\mathrm{NO}_{2}-\mathrm{N}\right)$ & $\mathrm{mg} / \mathrm{l}$ & $4,76 \pm 1,056$ & $4,54 \pm 0,502$ & $3,8 \pm 0,878$ & $4,08 \pm 0,524$ & 6 \\
6 & $\mathrm{COD}$ & $\mathrm{mg} / \mathrm{l}$ & $44 \pm 16,653$ & $44 \pm 15,318$ & $50 \pm 27,227$ & $42 \pm 21,040$ & 50 \\
7 & Total fosfat sbg P & $\mathrm{mg} / \mathrm{l}$ & $0,704 \pm 0,467$ & $0,639 \pm 0,426$ & $0,737 \pm 0,536$ & $0,66 \pm 0,481$ & 1 \\
\hline
\end{tabular}

Proses dekomposisi bahan organik membutuhkan sejumlah besar oksigen. Kebutuhan oksigen semakin besar dengan makin meningkatnya kandungan limbah dalam perairan (Ghufran, 2007). Kehidupan makhluk hidup di dalam air tergantung dari kemampuan air mempertahankan konsentrasi oksigen minimal yang dibutuhkan untuk kehidupannya. Ikan merupakan makhluk air yang memerlukan oksigen terbesar, sedangkan bakteri memerlukan oksigen terkecil. Konsentrasi oksigen terlarut minimal untuk kehidupan biota tidak boleh kurang dari 6 ppm (Fardiaz, 1992). Kondisi oksigen terlarut dalam penelitian ini nilainya masih kurang memenuhi syarat untuk budidaya ikan nila.

Jumlah oksigen terlarut yang dibutuhkan oleh organisme hidup untuk memecah atau mengoksidasi bahan-bahan buangan di dalam air dapat diketahui dari nilai BOD (Biochemical Oxygen Demand) (Fardiaz, 1992). Nilai BOD dalam penelitian ini nilainya masih memenuhi syarat untuk budidaya perikanan. Sedangkan jumlah oksigen yang dibutuhkan oleh bahan oksidan untuk mengoksidasi bahan-bahan organik yang terdapat di dalam air dapat diketahui dari nilai COD (Chemical Oxygen Demand). Nilai COD dalam penelitian ini nilainya masih memenuhi syarat untuk budidaya ikan nila.

Kandungan nitrit $\left(\mathrm{NO}_{2}\right)$ dalam perairan menyebabkan racun bagi biota air karena mengoksidasi $\mathrm{Fe}^{2+}$ yang mengakibatkan kemampuan untuk mengikat oksigen rendah (Ghufran, 2007). Tingginya kadar nitrit dapat terjadi karena terdapatnya bahan organik dalam air berupa kandungan tepung kulit ubi kayu dari sisa pakan yang mengendap di dasar bak. Menurut (Hendrawati et al.,
2006) meningkatnya kadar nitrit berkaitan erat dengan bahan organik. Kondisi nitrit dalam air pada penelitian ini masih kurang memenuhi syarat budidaya ikan nila. Sedangkan kondisi total fosfat sebagai $\mathrm{P}\left(\mathrm{PO}_{4}\right)$ dalam penelitian ini nilainya masih memenuhi syarat untuk budidaya ikan nila. Secara keseluruhan berdasarkan hasil pengamatan kondisi fisika kimia air pada penelitian ini masih cukup memenuhi syarat untuk pertumbuhan dan peningkatan jumlah bakteri asam laktat serta budidaya ikan nila.

Pakan fermentatif yang mengandung bakteri asam laktat $\mathrm{MEP}^{+}$dapat memperbaiki kondisi lingkungan internal ikan yang berperan aktif dalam meningkatkan kecernaan pakan, sehingga pakan menjadi mudah diserap oleh usus. Jumlah kepadatan bakteri asam laktat usus ikan tersaji pada Tabel 4 .

Berdasarkan pengamatan secara kuantitatif kepadatan bakteri asam laktat usus ikan nila terjadi peningkatan jumlah koloni pada masing-masing perlakuan rata-rata jumlahnya berkisar $5,83 \times 10^{5}$ cfu's/ml sampai $27,39 \times 10^{5}$ cfu's/ml. Hal ini menunjukan bahwa bakteri asam laktat $\mathrm{MEP}^{+}$mampu bertahan hidup di dalam usus ikan. Menurut Kompiang (2009) mikroba probiotik yang hidup atau berkembang dalam usus dapat menguntungkan inangnya baik secara langsung maupun tidak langsung dari hasil metabolitnya.

Pakan ikan yang diberikan telah dilakukan fermentasi. Hal ini bertujuan untuk meningkatkan kadar protein dalam pakan. Peningkatan kadar protein dan penurunan kadar serat kasar tersaji pada Tabel 5. 
Tabel 4. Jumlah kepadatan bakteri asam laktat usus ikan nila (cfu's/ml) pada setiap perlakuan selama 9 minggu pemeliharaan

\begin{tabular}{|c|c|c|c|c|c|c|c|}
\hline \multirow{2}{*}{ No. } & \multirow{2}{*}{ Perlakuan } & \multicolumn{4}{|c|}{ Minggu ke- } & \multirow{2}{*}{ Jumlah } & \multirow{2}{*}{ Rata-rata } \\
\hline & & 0 & 3 & 6 & 9 & & \\
\hline 1. & A & $5,20 \times 10^{5}$ & $5,33 \times 10^{5}$ & $4,15 \times 10^{5}$ & $26,80 \times 10^{5}$ & $41,48 \times 10^{5}$ & $10,37 \times 10^{5}$ \\
\hline 2. & B & $5,15 \times 10^{5}$ & $5,20 \times 10^{5}$ & $1,67 \times 10^{5}$ & $11,30 \times 10^{5}$ & $23,32 \times 10^{5}$ & $5,83 \times 10^{5}$ \\
\hline 3. & $\mathrm{C}$ & $5,1 \times 10^{5}$ & $5,12 \times 10^{5}$ & $18,60 \times 10^{5}$ & $26,80 \times 10^{5}$ & $51,62 \times 10^{5}$ & $12,91 \times 10^{5}$ \\
\hline 4. & $\mathrm{D}$ & $5 \times 10^{5}$ & $5,15 \times 10^{5}$ & $3 \times 10^{5}$ & $96,40 \times 10^{5}$ & $109,55 \times 10^{5}$ & $27,39 \times 10^{5}$ \\
\hline & Total & & & & & $225,97 \times 10^{5}$ & $56,5 \times 10^{5}$ \\
\hline
\end{tabular}

Tabel 5. Hasil analisis proksimat protein kasar dan serat kasar pada masing-masing formulasi pakan sebelum dan sesudah fermentasi

\begin{tabular}{|c|c|c|c|c|c|c|c|c|}
\hline \multirow{3}{*}{ Analisis } & \multicolumn{8}{|c|}{ Formulasi pakan (\%) } \\
\hline & \multicolumn{2}{|c|}{ A } & \multicolumn{2}{|c|}{ B } & \multicolumn{2}{|c|}{$\mathrm{C}$} & \multicolumn{2}{|c|}{$\mathrm{D}$} \\
\hline & Sebelum & Sesudah & Sebelum & Sesudah & Sebelum & Sesudah & Sebelum & Sesudah \\
\hline Protein kasar & 13,21 & 15,46 & 9,66 & 11,53 & 8,34 & 9,87 & 13,21 & 15,46 \\
\hline Serat kasar & 32,10 & 25,25 & 24,23 & 19,38 & 18,37 & 15,79 & 32,10 & 25,25 \\
\hline
\end{tabular}

Berdasarkan pengamatan terjadi peningkatan protein kasar pada masing-masing perlakuan. Selisih peningkatan protein kasar berkisar antara 1,53\% sampai dengan 2,25\%. Peningkatan protein terjadi dikarenakan adanya proses fermentasi. Menurut Medikasari et al (2009) tepung ubi kayu dengan fermentasi mampu meningkatkan kandungan protein pada tepung sehingga dapat digunakan sebagai sumber protein pada makanan. Kadar serat kasar yang terkandung dalam pakan pada masing-masing perlakuan terjadi penurunan setelah dilakukan fermentasi. Selisih penurunan serat kasar berkisar antara 2,58 \% sampai 6,85\%. Serat kasar tersebut di dekomposisi oleh bakteri $\mathrm{MEP}^{+}$. Bakteri $\mathrm{MEP}^{+}$yang berperan sebagai jasad pencerna serat kasar (selulosa) yaitu $C$. cellasea. Terjadinya peningkatan protein kasar dan penurunan serat kasar setelah dilakukan fermentasi mengakibatkan pakan yang termakan ikan menjadi mudah di serap usus. Usus yang dapat menyerap baik makanan, maka feses yang dikeluarkan lebih sedikit dan tidak mencemari lingkungan perairan.

\section{KESIMPULAN DAN SARAN}

Pemberian $\mathrm{MEP}^{+}$pada medium budidaya dan pakan fermentatif berbahan tepung kulit ubi kayu tidak menyebabkan terjadinya peningkatan kepadatan bakteri asam laktat medium budidaya ikan nila, ratarata kepadatan yang diperoleh relatif tidak jauh berbeda yaitu berkisar $1,23 \times 10^{3} \mathrm{sel} / \mathrm{ml}$ sampai $2,12 \times 10^{3} \mathrm{sel} / \mathrm{ml}$. Kepadatan bakteri asam laktat medium budidaya ikan nila jumlahnya tidak berbeda antar tiap perlakuan

Pemberian $\mathrm{MEP}^{+}$sebanyak $10 \mathrm{ml}$ (1 tutup botol kemasan $\mathrm{MEP}^{+}$) dalam $108 \mathrm{ml}$ air pada bak percobaan dan pakan yang disemprot dengan $\mathrm{MEP}^{+}$tidak efektif dalam meningkatkan kepadatan bakteri asam laktat pada medium budidaya ikan, sehingga perlu dilakukan penelitian lebih lanjut mengenai dosis pemberian $\mathrm{MEP}^{+}$yang sesuai untuk diaplikasikan pada medium budidaya maupun pakan fermentatif, sehingga dapat meningkatkan kepadatan bakteri asam laktat dalam memperbaiki kualitas medium budidaya ikan.

\section{DAFTAR PUSTAKA}

Fardiaz S. 1992. Polusi Air dan Udara. Jakarta: Kanisius.

Ghufran MHKK, Baso Tancung A. 2007. Pengelolaan Kualitas air dalam Budidaya Perairan. Jakarta: Rineka Cipta.

Hadi P. 2006. Pengaruh Pemberian Karbon (Sukrosa) dan Probiotik terhadap Dinamika Populasi Bakteri dan Kualitas Air Media budidaya Udang Vannamei, Litopenaeus vannamei [skripsi]. Bogor: Institut Pertanian Bogor.

Hadioetomo RS. 1993. Mikrobiologi Dasar dalam Praktek. Teknik dan Prosedur Dasar Laboratorium. Jakarta: PT Gramedia. 443h.

Hendrawati, Prihadi TH, Rohmah NN. 2006. Analisis Kadar Phosfat dan N-Nitrogen (Amonia, Nitrat, Nitrit) pada Tambak Air Payau Akibat Rembesan Lumpur Lapindo di Sidoarjo, Jawa Timur. Jurnal Valensi. 1(3): 133-141.

Kompiang, IP. 2009. Pemanfaatan Mikroorganisme sebagai Produksi untuk Meningkatkan Produksi Ternak Unggas di Indonesia. Jurnal Pengembangan Inovasi Pertanian. 2(3): 177191.

Medikasari, Marniza, Desiana E. 2009. Produksi Tepung Ubi Kayu Berprotein: Suatu Kajian Awal Karakteristik Berdasarkan Lama Fermentasi dan Jumlah Inokulum dengan Menggunakan Ragi Tempe. Lampung: Universitas Lampung; Seminar Hasil Penelitian dan Pengabdian Kepada Masyarakat.

Muhiddin NH, Juli N, Aryantha INP. 2001. Peningkatan Kandungan Protein Kulit Umbi Ubi Kayu Melalui Proses Fermentasi. Jurnal MS. 6(1): $1-12$.

Purwanta W, Firdayati M. 2002. Pengaruh Aplikasi Mikroba Probiotik pada Kualitas Kimiawi Perairan Tambak Udang. Jurnal Teknologi Lingkungan. 3(1): 61-65.

Siregar S. 2005. Statistik Terapan Untuk Penelitian. Jakarta : Grasindo.

Sukanto, Sutardi TR. 2008. Pengembangan Budidaya Ayam Broiler Secara Nonkonvensional Melalui Pemberian Probiotik MEP+. Jurnal Pengembangan Penerapan Teknologi. 4(1): 397-409.

Suprihatin. 2010. Teknologi Fermentasi. Surabaya: UNESA Press.

Suriawiria U. 1986. Mikrobiologi Air. Bandung: Alumni.

Suyanto SR. 1999. Nila. Jakarta: Penebar Swadaya.

Thayer DW, Lowther SV, Phillips JG. 1984. Cellulolytic Activities of Strains of the Genus Cellulomonas. Journal of Systematic Bacteriology. 34(4): 432 - 438.

Wahyudi AJ. 2008. Pengaruh Lama Pemberian Probiotik MEP terhadap Kelulusan Hidup Ikan Nila GIFT (Oreochromis sp.) yang di Uji Tantang Aeromonas hydrophila [skripsi]. Universitas Jenderal Soedirman-Purwokerto.

Widiada IGN. 2008. Karakterisasi Bakteri Asam Laktat Indigenous Hasil Isolasi dari Susu Kuda Liar Bima. Jurnal Kesehatan Prima. 2(2): $304-309$. 